\title{
NILAI GIZI, DAYA CERNA PROTEIN DAN DAYA TERIMA PATILO SEBAGAI MAKANAN JAJANAN YANG DIPERKAYA DENGAN HIDROLISAT PROTEIN IKAN MUJAIR (Oreochromis mossambicus)
}

\author{
Haslina $^{(1)}$, Siti Fatimah Muis ${ }^{(2)}$, Suyatno $^{(3)}$
}

\begin{abstract}
Introduction: Patilo is one of traditional various snacks from Gunung Kidul that is made of fermented cassava waste and cassava starch. Fermentation is intended to reduce or eliminate the HCN content of cassava and to establish special flavour. The protein content of patilo is very low, therefore it can be enriched with animal protein from fresh water fish in form of fish flour or fish protein hydrolysate (FPH). Enrichment with fish protein hydrolysate has an advantage since it will be easier to digest by human because FPH better functional properties and higher solubility.

Method: The study consisted of four activities that were 1) making/producing mujair FPH, 2) producing and enriched patilo with mujair FPH, 3) analyzed the nutritive values and protein digestibility of enriched and unenriched patilo and 4) analyzed the consumers acceptability of the products. The experiments were carried out in the 1) Food Engineering and Chemistry Laboratorium of Faculty of Agriculture Technology Semarang University, 2) Pilot Plan PAU and GMSK Laboratory of Bogor Institute of Agriculture, 3) Sidoardjo Village, Tepus Gunung Kidul. Variables being studied were nutritive value and protein digestibility of unenriched and enriched patilo with mujair FPH in several consumer acceptability in terms of flavour, taste, colour and texture. The study design was a complete random design of one factor in which the FPH was added in 5\%, 10\% and 15\% concentration, each treatment repeated 3 times. Statistical analyses used for nutritive value and protein digestibility were Anova followed by Least Significant Difference test with 0,05 level of significancy Friedman and Wilcoxon Sign Rank test were used to test the organoleptic values both in the laboratory and in the field.

Result:1) The nutritive value changes of raw enriched patilo were : a) significant decrease in water and carbohydrate content, b) significant increase in ash, fat and protein content compared to the unenriched patilo, 2) The nutritive value change of fried enriched patilo were : a) significant decrease in water and carbohydrate content, b) significant increase in fat, protein and energy content compared to the unenriched patilo, 3) The protein digestibility in raw and fried enriched patilo was significant higher than that without enrichement, 4) Patilo enriched with 10\% mujair FPH was mostly liked by consumer either in the laboratory or in the field in term of taste, flavour and texture as for colour, all consumers prefered the unenriched patilo, 5) The changes of the nutritive values and protein digestibility were statistically significant in the enriched patilo, however from the nutrition point of view, only the increased of protein content (six folds increase) was meaningful.

Conclusion: Patilo enriched with $10 \%$ mujair FPH is the most/well accepted by laboratory panelists and field consumers, and there was six folds increase in the protein content.
\end{abstract}

Key Word: Patilo, enrichment and fish protein hydrolysate.

\section{ABSTRAK}

Latar Belakang: Patilo adalah salah satu makanan jajanan tradisional Gunung Kidul yang diolah dari ampas singkong yang difermentasi dan dicampur dengan pati singkong. Kandungan protein dalam patilo sangat rendah, untuk itu perlu diperkaya antara lain dengan sumber protein hewani dari ikan air tawar baik dalam bentuk tepung ikan atau hidrolisat protein ikan (HPI). Tujuan: Penelitian ini bertujuan untuk 1). menganalisis nilai gizi patilo 2). menganalisis daya cerna protein patilo 3). menganalisis daya terima patilo goreng tanpa dan dengan penambahan HPI mujair Metode: Penelitian ini terdiri dari empat kegiatan yaitu: 1). pembuatan HPI

1. Alumnus Magister Gizi Masyarakat, Universitas Diponegoro.

2. Fakultas Kedokteran/Magister Gizi Masyarakat, Universitas Diponegoro

3. Fakultas Kesehatan Masyarakat/Magister Gizi Masyarakat, Universitas Diponegoro 
mujair, 2). pembuatan dan pengkayaan patilo dengan HPI mujair, 3). pengujian nilai gizi dan daya cerna protein patilo tanpa dan dengan penambahan HPI mujair dan 4). uji penerimaan patilo baik di laboratorium maupun di lapangan. Variabel yang diamati adalah kandungan gizi patilo dan daya cerna protein patilo. Rancangan percobaan yang digunakan adalah Rancangan Acak Lengkap dengan 1 faktor yaitu $H_{P I}=$ tanpa penambahan $\mathrm{HPI}, \mathrm{HPI}_{1}=$ penambahan $\mathrm{HPI} 5 \%$ dari berat ampas (b/b), $\mathrm{HPI}_{2}=$ penambahan $\mathrm{HPI} 10 \%$ dari berat ampas (b/b) dan $\mathrm{HPI}_{3}=$ penambahan $\mathrm{HPI} 15 \%$ dari berat ampas $(b / b)$, masing-masing perlakuan diulang sebanyak tiga kali. Analisis kandungan gizi dan daya cerna patilo dengan Anova, uji dilanjutkan dengan uji Least Significant Difference (LSD) pada taraf dan 5\%. Untuk analisis uji organoleptik baik di laboratorium maupun di lapangan dengan uji Friedman. Perbedaan hasil akan dilanjutkan dengan uji lanjut Wilcoxon Sign Rank Test.

Hasil: 1) Nilai gizi patilo mentah dengan penambahan HPI mujair dibandingkan tanpa penambahan HPI mujair adalah : a) terjadi penurunan kadar air dan kadar karbohidrat secara signifikan $(\rho<0,05)$ dan b) terjadi peningkatan kadar abu, kadar lemak dan kadar protein secara signifikan $(\rho<0,05), 2)$ Nilai gizi patilo goreng dengan penambahan HPI mujair dibandingkan tanpa penambahan HPI mujair adalah : a). terjadi penurunan kadar air dan kadar karbohidrat secara signifikan $(\rho<0,05)$ dan b).terjadi peningkatan kadar lemak, kadar protein dan energi secara signifikan $(\rho<0,05) 3)$. Daya cerna protein patilo mentah dan goreng dengan penambahan HPI mujair meningkat secara signifikan $(\rho=0,000)$ dibandingkan tanpa penambahan HPI mujair pada seтиa konsentrasi, 4). Patilo dengan penambahan HPI mujair 10\% paling disukai oleh panelis agak terlatih dan panelis konsumen anak sekolah berdasarkan skor rasa, bau dan tekstur. Untuk warna, panelis agak terlatih dan panelis konsumen anak sekolah memilih patilo tanpa penambahan HPI mujair dan 5). Secara statistik perubahan nilai gizi dan daya cerna protein bermakna kecuali untuk kadar abu patilo goreng, namun dari sudut gizi perubahan yang berarti hanya pada kadar protein yang mencapai 6 kali lipat.

Simpulan: Patilo yang diperkaya dengan HPI mujair 10\% paling disukai oleh panelis agak terlatih maupun panelis konsumen anak sekolah dan terjadi kenaikan secara signifikan pada kadar protein yang mencapai 6 kali lipat.

Kata Kunci : Patilo, pengkayaan dan hidrolisat protein ikan

\section{PENDAHULUAN}

Kurang Energi Protein (KEP) merupakan salah satu penyakit gangguan gizi yang masih banyak terjadi di Indonesia, dimana prevalensi yang tinggi terdapat pada anak-anak di bawah umur 5 tahun (balita), ibu hamil dan ibu menyusui (Pudjiadi, 1992). KEP dapat terjadi sebagai akibat asupan makanan yang tidak cukup mengandung energi dan protein serta karena adanya infeksi kronik atau berulangulang. Tersedianya berbagai jenis makanan bergizi dan berdaya cerna tinggi, dapat dipenuhi antara lain melalui pengkayaan makanan dengan bahan-bahan yang memenuhi persyaratan yang sangat diperlukan untuk meningkatkan asupan makanan pada anak-anak maupun orang dewasa.

Di antara kelompok pangan hewani, ikan sebagai sumber protein setelah diolah dengan cara tertentu dapat dipakai sebagai bahan pengkayaan makanan/jajanan olahan, mengingat kandungan protein ikan cukup tinggi (15-24\%), asam amino esensialnya lengkap, daya cerna sangat tinggi yaitu 95\% serta mengandung asam lemak omega-3 yang berguna untuk kesehatan, pertumbuhan dan kecerdasan anak (Rahayu et al., 1992; Hadju et al., 1998). Pengolahan ikan menjadi hidrolisat protein bertujuan untuk mengatasi kerusakan ikan dan untuk mendapatkan bahan pangan yang lebih mudah dicerna oleh tubuh karena proteinnya telah terurai menjadi asam amino dan peptida-peptida yang lebih sederhana. Hidrolisat protein ikan (HPI) adalah protein ikan yang telah terurai menjadi turunanturunan protein karena adanya proses hidrolisis oleh enzim, asam ataupun basa. HPI mempunyai sifat fungsional yang lebih baik daripada tepung ikan karena mempunyai kelarutan yang sangat tinggi dan kelarutan ini tidak banyak berubah walaupun mendapat perlakuan suhu tinggi misalnya pada proses sterilisasi mampu bertahan dalam bentuk cair pada konsentrasi tinggi (Frokjaer, 1994; Lahl 
\& Steven, 1994). Beberapa penelitian di Jepang mengungkapkan bahwa beberapa produk olahan yang memanfaatkan hidrolisat protein karena sifat fungsionalnya yang baik untuk sup, bumbu dalam kecap (penambah flavor), minuman berprotein tinggi, biskuit dan saos (Barzana \& Garcia, 1994; Synowiecki et al., 1996). Menurut Venugopal (1994), HPI juga berguna sebagai bahan pengganti susu, untuk fortifikasi produk makanan olahan seperti serealia, roti serta kerupuk. HPI dapat dibuat dari bahan ikan yang bernilai ekonomis rendah seperti ikan mujair (Orechromis mossambicus) di mana ikan tersebut merupakan sejenis ikan air tawar yang pertumbuhannya relatif lebih cepat dan sangat toleran terhadap lingkungan. Ikan jenis ini banyak dikonsumsi masyarakat karena harganya relatif tidak mahal dan merupakan sumber zat gizi yang baik.

Patilo adalah salah satu makanan jajanan tradisional Gunung Kidul yang diolah dari ampas singkong yang difermentasi dan dicampur dengan pati singkong. Produk ini biasa dikonsumsi sebagai pelengkap makan dan camilan yang sangat disukai masyarakat Gunung Kidul. Data konsumsi per kapita penduduk terhadap produk tersebut belum tersedia, tetapi data produksi tersebut cukup besar yaitu rata-rata $20.615 \mathrm{~kg} /$ bulan. Mengingat tingkat konsumsi ikan masyarakat Gunung Kidul, Yogyakarta yang masih rendah yaitu 4,7 kg/kapita/tahun (Dinas Perikanan dan Kelautan Kabupaten Gunung Kidul, 2003) dan kesukaan terhadap produk patilo sebagai pelengkap makan atau camilan cukup tinggi, maka usaha patilo diperkaya dengan sumber protein hewani dari ikan air tawar diharapkan dapat meningkatkan konsumsi protein bagi penduduk daerah tersebut.

Tujuan penelitian ini adalah untuk mengetahui pengaruh penambahan HPI mujair terhadap kadar protein dan daya terima patilo.

Penelitian ini diharapkan dapat memberikan informasi kepada masyarakat tentang pengaruh penambahan HPI mujair terhadap kadar protein dan daya terima patilo.

\section{BAHAN DAN METODE}

\section{Bahan Pembuatan HPI Mujair}

Bahan baku pembuatan HPI adalah ikan mujair (Mossambicus oreochromis) segar, dengan panjang berkisar antara $25-30 \mathrm{~cm}$ dan berat utuh 300-400 g/ekor yang diperoleh dari pasar lokal. Preparasi fillet dilakukan dengan cara yaitu ikan disiangi (dibuang kepala, sirip dan jeroan) kemudian dicuci sampai bersih. Tahap selanjutnya adalah ikan mujair disayat dengan cara memisahkan daging dari tulang. Daging ikan mujair hasil penyayatan kemudian ditimbang untuk mendapatkan nilai rendemen daging ikan. Selanjutnya daging ikan segar kemudian dicacah dengan pisau sampai lumat, kemudian daging lumat dicampur dengan enzim. Enzim yang digunakan adalah enzim papain (Merck) komersial diperoleh dari agen kimia.

\section{Bahan Pembuatan Patilo dengan Penambahan HPI Mujair}

Bahan baku yang digunakan yaitu ampas singkong dan pati singkong serta tepung HPI mujair.

\section{Metode}

\section{Pembuatan HPI Mujair}

\section{Cara}

Proses pembuatan HPI dilakukan berdasarkan modifikasi dari metode pembuatan hidrolisat protein ikan oleh Gesualdo dan Li-Chan (1999). Proses hidrolisa diawali dengan menyiapkan daging ikan mujair. Setelah dibersihkan, daging ikan dicampur dengan air dengan perbandingan 1:4, kemudian dihomogenisasi menggunakan blender selama dua menit. Campuran yang telah terbentuk diaduk dan nilai $\mathrm{pH}$ campuran diatur hingga 7 pada suhu $55^{\circ} \mathrm{C}$ untuk menghasilkan aktivitas enzim yang optimal. Papain ditambahkan dengan konsentrasi $0,10 \%(\mathrm{~b} / \mathrm{b})$ terhadap total bobot protein pada daging mujair. 
Pengadukan dilakukan terus menerus pada suhu $55^{\circ} \mathrm{C}$ selama 80 menit. Pengambilan sampel dilakukan setiap 10 menit sekali dengan tujuan untuk mengukur $\mathrm{pH}$, kemudian dilakukan penyaringan. Aktivitas enzim dihentikan dengan menaikkan suhu pengadukan antara $75-85^{\circ} \mathrm{C}$ selama 56 menit. Hidrolisat protein ikan disentrifuge dengan kecepatan 16300 x g selama 15 menit. Selanjutnya dilakukan dekantasi, kemudian fraksi terlarut dikeringkan dengan spray dryer. Fraksi terlarut dibekukan dan disimpan di dalam botol kemasan pada suhu $4^{\circ} \mathrm{C}$ untuk dianalisis.

\section{Pembuatan Patilo dengan Penambahan HPI Mujair}

\section{Cara}

Ampas singkong dimasukkan ke dalam bakul yang telah dialasi dengan daun pisang, kemudian diikat seperlunya. Pemeraman dilakukan selama 3 hari. Selama pemeraman, akan terjadi fermentasi dan timbul rasa asam (Soetanto, 2001). Kemudian tepung HPI mujair dicampur dengan ampas singkong hasil fermentasi selama 3 hari dan pati singkong. Campuran bahan diaduk dengan penambahan air sedikit demi sedikit sehingga terbentuk adonan yang homogen, kemudian dilakukan pemberasan (penggelintiran). Adonan yang telah jadi kemudian dicetak dengan ukuran diameter $5 \mathrm{~cm}$ dengan ketebalan $0,3 \mathrm{~cm}$. Setelah itu dikukus selama 5 menit, kemudian dikeringkan dengan oven suhu $60^{\circ} \mathrm{C}$ selama 4-5 jam.

Selanjutnya patilo dimasukkan ke dalam minyak goreng panas sambil dipanasi dengan api kecil, kemudian api dibesarkan sampai patilo mengapung. Patilo yang telah masak didinginkan, selanjutnya dikemas dalam kantong plastik.

Rancangan percobaan yang digunakan pada penelitian ini adalah Rancangan Acak Lengkap (RAL) dengan 4 perlakuan dan 5 kali ulangan adalah $\mathrm{A}_{1}$ (tanpa HPI mujair), $\mathrm{A}_{2}$ (HPI mujair $5 \%$ ), $\mathrm{A}_{3}$ (HPI mujair $10 \%$ ) dan $\mathrm{A}_{4}$ (HPI mujair $15 \%)$.

\section{HASIL DAN PEMBAHASAN}

\section{Kandungan Zat Gizi HPI Mujair Kadar Air}

Kadar air HPI mujair (3\%) lebih rendah dibandingkan dengan tepung ikan lainnya yaitu tepung ikan gabus $(21,5 \%)$, tepung ikan tuna $(8,8 \%)$ dan tepung ikan lemuru $(7,4 \%)$, khususnya dalam hal lama dan suhu pengeringan. Proses pengeringan sangat mempengaruhi kadar air HPI mujair. Berdasarkan syarat kadar air untuk tepung yang ditetapkan menurut SII yaitu maksimum sebesar 14\%, maka kadar air tepung HPI mujair telah memenuhi persyaratan tersebut. Tepung HPI mujair dengan kadar air yang cukup rendah memberikan keuntungan yaitu daya simpan yang lebih baik. Menurut Winarno (1997), kadar yang rendah dapat mencegah atau menghambat pertumbuhan mikroorganisme perusak.

\section{Kadar Abu}

Bila dibandingkan dengan kadar abu dari tepung ikan lain maka kadar abu yang terdapat pada tepung HPI mujair (1\%) lebih rendah dan hanya tepung tuna $(2,5 \%)$ saja yang mendekati. Berdasarkan syarat kadar abu yang ditetapkan dalam SII yaitu maksimum $30 \%$, ternyata tepung HPI mujair yang dihasilkan telah memenuhi syarat. Tinggi rendahnya kadar abu tepung tergantung dari jenis bahan bakunya.

\section{Kadar Lemak}

Kadar lemak tepung HPI mujair $(3,1 \%)$ lebih tinggi bila dibandingkan dengan tepung ikan tuna $(1 \%)$ namun lebih rendah dari tepung ikan lemuru (10\%). Berdasarkan standar lemak tepung ikan yaitu antara 5\%-10\% yang ditetapkan oleh laboratorium pembinaan dan pengujian mutu hasil perikanan, tepung HPI mujair mendekati persyaratan mutu tepung ikan dengan kadar lemak sebesar 3,1\%. Lemak adalah unsur yang penting dalam bahan pangan sebagai sumber energi. Namun pada tepung, kadar lemak yang rendah sangat diharapkan karena dengan kadar yang rendah mutu tepung 
menjadi semakin baik. Daya simpan tepung menjadi semakin tinggi dengan semakin rendahnya kadar lemak, karena proses oksidasi lemak dapat dihindari sehingga ketengikan pada bahan tidak terjadi.

\section{Kadar Protein}

Kadar protein ikan mujair sebesar $18,1 \%$, sedangkan setelah diolah menjadi tepung HPI mujair meningkat menjadi $92,9 \%$. Hal ini karena tepung HPI mujair mempunyai kadar air yang sangat rendah sehingga menyebabkan kadar protein meningkat.

\section{Pengaruh Penambahan HPI Mujair Terhadap Kadar Protein Patilo}

Hasil analisis ragam menunjukkan bahwa penambahan HPI mujair berpengaruh terhadap kadar protein patilo mentah maupun goreng. Berdasarkan hasil uji LSD terlihat bahwa baik pada patilo mentah maupun goreng ada perbedaan yang bermakna dalam kandungan protein antar kelompok.

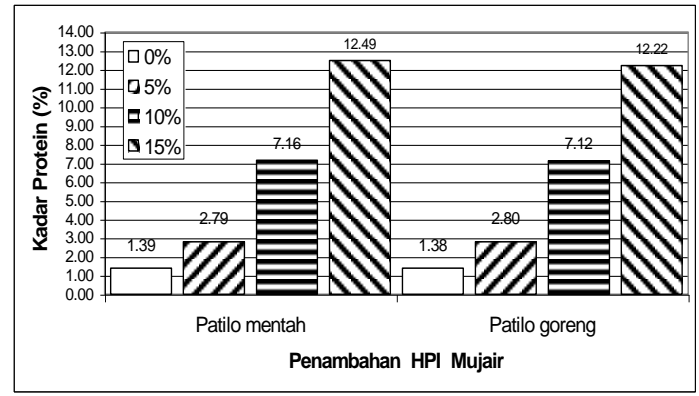

Gambar 1. Histogram rerata kadar protein patilo

Kadar protein patilo mentah dengan penambahan HPI mujair lebih tinggi dibanding dengan tanpa penambahan HPI mujair. Kadar protein patilo goreng dengan penambahan HPI mujair juga lebih tinggi daripada yang tidak ditambah HPI mujair. Kenaikan kadar protein disebabkan oleh penambahan HPI mujair serta penurunan kadar air. Tepung HPI mujair berkadar protein tinggi $(92,9 \%)$, hingga diduga semakin besar penambahan tepung HPI mujair, semakin banyak protein yang terekstrak atau terlarut. Hal ini sesuai pendapat Guyton (1983) yang menyatakan bahwa proses pemanasan protein dalam air pada suhu $50^{\circ} \mathrm{C}$ menyebabkan terjadinya pengembangan atau pembukaan lipatan protein menjadi bentuk yang terbuka. Ikatan peptida yang terbuka akan memudahkan enzim berhubungan dengan protein. Hidrolisat protein yang semakin banyak akan menghasilkan rantai peptida yang semakin pendek yang berarti berat molekul berkurang. Dengan demikian kelarutan protein meningkat.

\section{Daya Terima Terhadap Warna}

Berdasarkan penilaian 25 orang panelis diketahui bahwa sebanyak $64 \%$ panelis menyukai warna patilo tanpa penambahan HPI mujair. Hal ini disebabkan warna HPI mujair adalah coklat, yang akan menyebabkan patilo yang diberi HPI mujair menjadi berwarna lebih tua daripada yang tanpa HPI mujair. Patilo tanpa HPI mujair berwarna lebih muda daripada yang ditambah HPI mujair.

Perlakuan tingkat penambahan HPI mujair mempengaruhi daya terima terhadap warna patilo. Hal ini disebabkan oleh pengaruh warna dari HPI mujair. Dengan semakin tinggi tingkat penambahan HPI mujair daya terima terhadap warna patilo semakin menurun, karena warna yang dihasilkan menjadi lebih coklat setelah digoreng dan kurang menarik.

\section{Daya Terima Terhadap Rasa}

Berdasarkan penilaian 25 orang panelis diketahui bahwa sebanyak $72 \%$ panelis menyukai rasa patilo dengan penambahan HPI mujair sebesar $10 \%$. Penambahan HPI mujair akan menyebabkan rasa gurih. Konsumen lebih memilih patilo dengan penambahan HPI mujair $10 \%$ daripada $15 \%$ karena HPI mujair $15 \%$ sedikit pahit, sedang HPI mujair 5\% tidak segurih HPI mujair 10\%. Rasa patilo dipengaruhi oleh penambahan tepung HPI mujair. Pada umumnya produk hidrolisat protein berasa pahit karena adanya senyawa peptida berantai pendek (Aubes-Dufau et al., 1995), akan tetapi dalam penelitian ini rasa 
pahit HPI mujair tidak terlampau mencolok karena telah tertutup oleh rasa asin yang berasal dari enzim papain yang digunakan untuk menghidrolisis daging ikan (Ariyani et al., 1999) sehingga rasa asin tersebut terbawa pada produk hasil pengkayaannya. Beberapa panelis memberikan komentar adanya rasa gurih pada patilo hasil pengkayaan HPI mujair. Hal ini dapat dimengerti karena salah satu produk hidrolisis protein ikan adalah oligopeptida yang mempunyai proporsi molaritas yang tinggi dari asam glutamat (Barzana \& Garcia, 1994).

\section{Daya Terima Terhadap Bau}

Bau patilo sangat dipengaruhi oleh tingkat penambahan HPI mujair. Berdasarkan daya terima terhadap bau, yang paling disukai pada patilo yang ditambah HPI mujair 10\% dengan skor 3,2. Hal ini karena adanya bau khas dari ikan yang terdapat pada tepung HPI mujair

\section{Daya Terima TerhadapTekstur}

Tekstur yang paling disukai oleh panelis agak terlatih pada patilo yang ditambah HPI mujair $10 \%$ dengan skor 3,5. Hal ini diduga karena di dalam proses pembuatan adonan patilo dengan tepung HPI mujair sebesar 10\% lebih homogen jika dibanding dengan yang dihasilkan dari penambahan tepung HPI mujair sebesar 5\% dan $15 \%$, dimana homogenitas adonan merupakan faktor terpenting, karena sifat ini dapat mempengaruhi keseragaman produk akhir yang dihasilkan, campuran dapat menjadi homogen. Selain itu pengukusan juga akan mempengaruhi tekstur. Pengukusan pada dasarnya untuk menghasilkan tekstur yang lebih kompak, produk menjadi matang dan dapat langsung dimakan (Lund, 1984). Demikian juga dengan proses pengeringan, dimana pengeringan patilo mempunyai tujuan menyediakan bahan dengan kadar air tertentu dimana adanya air akan mengurangi kualitas atau kapasitas pengembangan patilo dalam proses penggorengan selanjutnya
Cara menggoreng juga mempengaruhi tekstur patilo yang dihasilkan. Menurut Weiss (1983), suhu minyak yang baik untuk menggoreng berkisar antara $168^{\circ} \mathrm{C}-196^{\circ} \mathrm{C}$ tergantung bahan yang digoreng. Suhu minyak yang rendah (kurang dari $168^{\circ} \mathrm{C}$ ) menyebabkan terjadinya kekerasan yang tidak diinginkan pada makanan, sedangkan untuk minyak dengan suhu yang tinggi (lebih dari $196^{\circ} \mathrm{C}$ ) akan menyebabkan makanan gosong pada bagian luar sedangkan pada bagian dalam belum matang.

\section{Penilaian Umum}

Berdasarkan hasil penilaian secara umum oleh panelis agak terlatih dan konsumen, patilo dengan penambahan HPI mujair sebesar $10 \%$ yang paling disukai berdasarkan skor rasa, bau dan tekstur dengan rerata keseluruhan skor 3,6. Untuk warna, panelis memilih patilo tanpa penambahan HPI mujair.

\section{SIMPULAN}

1. Kadar protein patilo mentah dan goreng dengan penambahan HPI mujair meningkat secara signifikan $(\rho=0,000)$ dibandingkan tanpa penambahan HPI mujair pada semua konsentrasi.

2. Patilo dengan penambahan HPI mujair $10 \%$ paling disukai oleh panelis agak terlatih berdasarkan skor rasa, bau dan tekstur. Untuk warna, panelis agak terlatih memilih patilo tanpa penambahan HPI mujair.

\section{DAFTAR PUSTAKA}

Ariyani, F., Saleh, M., Tazwir dan Haq, N. 1999. Penelitian Kondisi Optimal Pembuatan HPI secara Enzimatis. Laporan Teknis Penelitian Preparasi Hidrolisat Protein Ikan (HPI) sebagai Bahan Fortifikasi Pangan, Jakarta. Instalasi Penelitian Perikanan Laut Slipi. Balai Penelitian Perikanan Laut, Puslitbangkan: 1-74. 
Aubes-Defau, I., Seris, J, and Combes, d. 1995. Production of peptic hemoglobin hydrolysates: Bitterness demonstration anc characterization. $J$. Agric Food Chem. 43: 1982-1988.

Barzana, E dan Garcia, G.N. 1994. Production of fish protein concentrate. Martin, A.M. (ed). Fisherles Processing Biotechnology Applications, London Chapman \& Hall: 207-222.

Dinas Perikanan dan Kelautan 2002. Laporan Tahunan Perikanan dan Kelautan Jawa Tengah, Pemerintah Propinsi Jawa Tengah: 92-96.

Frokjaer, S. 1994. Use of hydrolysate for protein supplement. Food Technology: 86-88.

Gesualdo, A.M.L \& Li-Chan. E.C.Y. 1999. Functional properties of fish protein hydrolysate from herring (Clupea harengus). Journal of Food Science .64 (6): :1000-1004.

Guyton, A.C., 1983. Buku Ajar Fisiologi Kedokteran. Edisi ke tujuh. Penerbit Buku Kedokteran. Universitas Indonesia E.G.C. Jakarta.

Hadju, V., Metusalach \& Karyadi. D. 1998. Pangan Potensial umtuk Meningkatkan Pertumbuhan Fisik, Daya Pikir dan Produktivitas serta Mencegah Penyakit Degeneratif. Prosiding Widyakarya Nasional Pangan dan Gizi VI, LIPI, Jakarta: 819839.

Lahl, W.J dan Steven, D.B. 1994. Enzymatic Production of Protein Hydrolysate for Food Use. Food Technology: 69-71.
Lund, D.B. 1984. Impact of Industrial Cooking of Food on Its Nutritional and Quality Characteristic dalam Thermal Processing and Quality of Foods. London \& New York. Elsevier A.S.Publ.: 291-299.

Pudjiadi, S. 1992. Ilmu Gizi Klinis pada Anak, Jakarta. Penerbit Balai Penerbit FKUI: 92-135.

Rahayu, W.P, Ma'oens S., Suliantari, Fardiaz. D. 1992. Teknologi Fermentasi Produk Perikanan. Bogor. Departemen Pendidikan dan Kebudayaan, Direktorat Jenderal Pendidikan Tinggi, Pusat Antar Universitas Pangan Gizi, IPB: 3-18.

Soetanto, E. 2001. Membuat Patilo dan Kerupuk Ketela. Teknologi Tepat Guna. Yogyakarta. Penerbit Kanisius: 1-55.

Synowiecki, J., Jagielka, E. dan Shahidi, F. 1996. Preparation of hydrolysates from bovine red blood cells and their debittering following plastein reaction. Food Chem. 57 (3) : 435-439.

Venugopal, V. 1994. Production of Fish Protein Hydrolysateby Microorganisme Concentrate. in Martin, AM (ed) Fisherles Processing Biotechnology Applications, London. Chaman \& Hall: 223-243

Weiss, T.J. 1983. Food Oil and Their Uses. Chichester England. Second Edition Ellis Harwood Limited Publishers: 157-173.

Winarno, F.G. 1997. Kimia Pangan dan Gizi. PT.Gramedia. Jakarta: 4-13. 